\title{
Research on Design of the Network Multimedia Courseware based on Wireless Sensor Networks for Art Design Teaching
}

\author{
Meini Xiong ${ }^{1, *}$ \\ ${ }^{1}$ College of Fine Arts, Beihua University, Jilin City, China
}

\begin{abstract}
Network teaching plays an important role in modern teaching with development of multimedia information technology. Therefore, how to design the network multimedia courseware for art design teaching in order to improve the teaching quality is a key problem in the network teaching environment, which can meet requirements of art design innovation and provide an important approach to the art design teaching.
\end{abstract}

\section{Introduction}

The rapid development of multimedia technology and computer network technology, not only affects the human mode of production and way of life, but also affect people's education and learning. Since the 1990s, the computer as the representative of modern information technology is widely used in the field of education, a variety of new disciplines theories, such as: new discipline system science, education, psychology, communication studies, information science theory has been rapid development. Not of a variety of new theoretical discipline also contributed to the development and improvement of education reform will be developed, and continue to introduce new topics, it's all theoretical education in the promotion of technical disciplines, practice and application of profound change.

Throughout the development process of information education at home and abroad, it has entered a new stage of development, popularization and application of computer technology, network technology and virtual technology is a huge blow to the traditional mode of education. Some countries, such as the US, UK distance education, opening this, Germany and other developed countries in the level of development on the scale, technically be significantly higher than China. In China, in recent years, the rapid development of China Distance Education, Ministry of Education approved 67 universities de-flop modern distance education pilot project, the creation of engineering, management, medicine, literature, science, agronomy, economics, education, law, philosophy 10 more than 140 professional large disciplines, has opened nearly 2, 000 modern Distance Education Learning Centres, total registered more than 160 million online education students. In addition, China has nearly $70 \%$ of the universities to establish a campus network, and the use of campus network to carry out teaching digital libraries, online courseware and teaching resources development application projects.

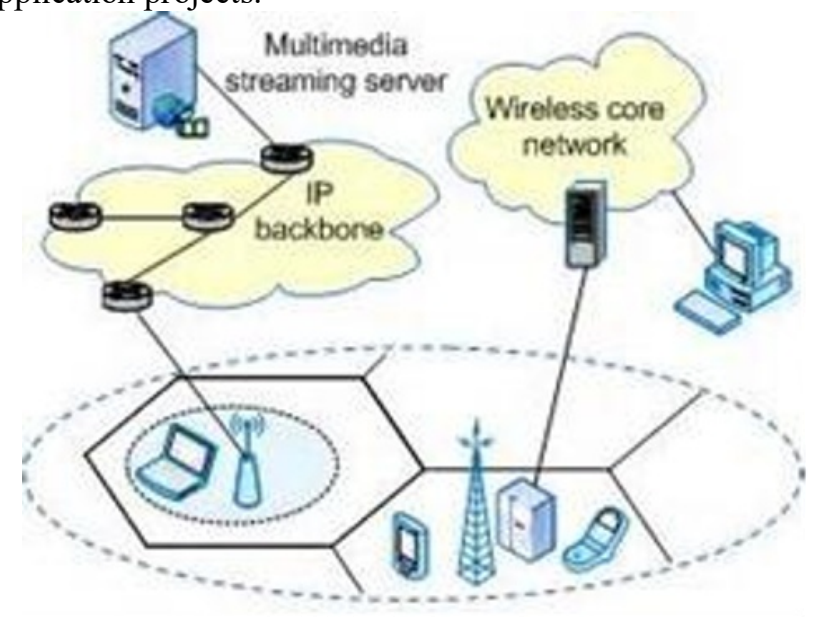

Fig. 1. Multimedia technology and computer network technology under network information background

\section{Multimedia network teaching has changed}

Twenty-first century, the competition of comprehensive national strength will be mainly reflected in the competition for talent, and the training of personnel, the key to education. Because of the future society of workers put forward higher requirements, require people to learn new knowledge to meet the needs of the times, so that the goal of education a fundamental shift will occur, in addition to the traditional school education, continuing education and lifelong learning become a way of life in the society of the future must become a key to the 21 st century, teachers are required to teach students not only knowledge, but also should teach students how to acquire knowledge. Social learner requirements will be reflected in future popularity, life, globalization and personalization features, educational requirements to 
provide large coverage, in many ways; a full range of services to ensure that any person at any time, any place required accepting the fundamental goal of any education is the future of education. Traditional education due to limitations and lack of location, faculty and other teaching resources cannot meet the requirements of the future of education. The multimedia network teaching changed all that, text, sound, graphics, images, animation and video and other media integrated together to make knowledge more abundant sources of information, greater capacity, more substantial, more vivid. It meets the learner to continue learning and lifelong learning requirements. It turned into the traditional classroom and virtual classroom space without time restrictions, so in order to explain and writing on the blackboard-based teaching model into new teaching mode for text, audio, animation, audio and video and other media coexistence. It enables students from passive acceptance to active learning, arrangements for the transition from the teaching content is dull, monotonous sequence of vivid, colourful, leaping teaching content arrangements. Multimedia network teaching has changed, "teaching" and "learning" the traditional concept, which greatly promoted the innovative educational methods.

Therefore, training to master high-tech innovative talents, to build life-long learning system is the development of higher education in the 21 st century. In the information society the use of information technology to improve the efficiency of higher education institutions, to expand the scope of the main contents educated people, explore new teaching model, has become the world of higher education reform and development. Under this environment, art and design education has also ushered in the best opportunities for development. Arts education will focus on information technology and produce new changes, along with the deepening of reform design education, art and design education in the information age will also be full of new vitality.

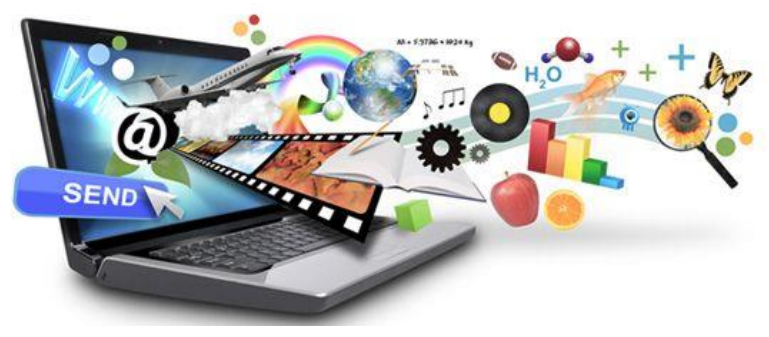

Fig. 2.Computer information acquisition system

\section{Overview of network multimedia courseware}

Courseware is a Web-browser, the use of certain techniques, according to certain teaching objectives, the performance of certain teaching content, teaching strategy that reflects, with a certain interactivity, which can be used for the purpose of assisted teaching multimedia package. Courseware (Web-Based Courseware) is based on the Browser/Server (browser/server) model developed specifically for teaching activities designed courseware can be released at work internet (the Internet), and it has the following characteristics.

Information society, students acquire learning resources not only from teachers to impart knowledge and books, more resources are derived from the distribution of resources on the Internet around the world, we can even link to any website based on up to learn. Interactivity can be understood as a dialogue or contacts communicate with each other or pass each other information. Since it is a teaching courseware role to play in order to achieve effective teaching, we must realize communication, learners and learner communication trainer and learner these basic communication. For example: via on-line interactive features, students can freely express, discuss their problems, some knowledge of the questions or their own experiences can be brought up for discussion in the whole course of the discussions, they may encounter with their completely different view to further encourage them to think.

Courseware Since it is Web browser-based network environment, then it should have the teaching and learning process in the open character. Unlike traditional classroom instruction, online courses of study without time and space constraints, the learner can learn anytime, anywhere through the network and computers learn the length of time is not limited. Courseware is a certain interaction; it can be used to assist in teaching for the purpose of multimedia packages. Therefore, in the learning process flexible media, learners can online learning; learning can also be stored on the $\mathrm{CD}$ after downloading. Courseware Web form to the organization can be a lot of knowledge, including course information, a variety of course-related assistance and effective tools stored in the data delivery station network library, learners can be called according to their needs, the formation of individual Teaching.

In the traditional classroom, teaching and learning both performed in a fixed time and space. The network teaching it offers to learners is a virtual school environment, through network technology teaching in virtual classrooms, breaking the limitations of time and space, so that students can have immersive, learning in the classroom feeling. Courseware is required to achieve a certain degree of network technology, the means to achieve integrated applications both online teaching techniques, but also the crystallization teaching philosophy, teaching methods and teacher planning methods, is also an important means to assist learning.

\section{Relational databases and platforms}

\subsection{Learning resources database}

Learning platform relational database can be divided into three categories, learning resources database, test questions database and information management database. Systems based on different roles, which provide different services. Learning Resource database holds the main courseware resources to provide students with the relevant works, reference materials, after-school exercises and other data; it is assisted by technical staff 
teacher to complete its en-try work; to provide students with the query, browse functions; for teachers data query, browse, modify, add, and delete function.

\subsection{Quiz questions database}

Quiz questions database is mainly used for online quiz module. After that, teachers Log online quiz module can query the database to test questions, browse, modify, add, and delete functions. Also part of the teacher can also choose to add to the paper from the usual after-school exercises. For students in terms of quiz questions do online database only for examinations questions, submit papers done, the query results and the like.

\subsection{Information management database}

Information management database is mainly used for student information management, teacher information for authentication management, and user login. When the authentication, the need to provide the identification number and password to the user information management database query the appropriate information in the table, until the match geese before allowing users to $\log$ on to the learning platform. System maintenance personnel can add, delete user list. Student information management is to save student information for students to query and modify. For example, students can modify their own personal nickname, password, address, etc. Information management is to provide teachers for teachers query, change of personal information, and to provide access to students' personal information and academic records, etc., to help manage student learning. In addition, the relationships between three databases are interdependent. Learning Resources Database part exercises or as part of a database of exam test questions. The quiz questions in the exams results database will also serve as student and teacher personal information is stored in the correspond ding location information management database.

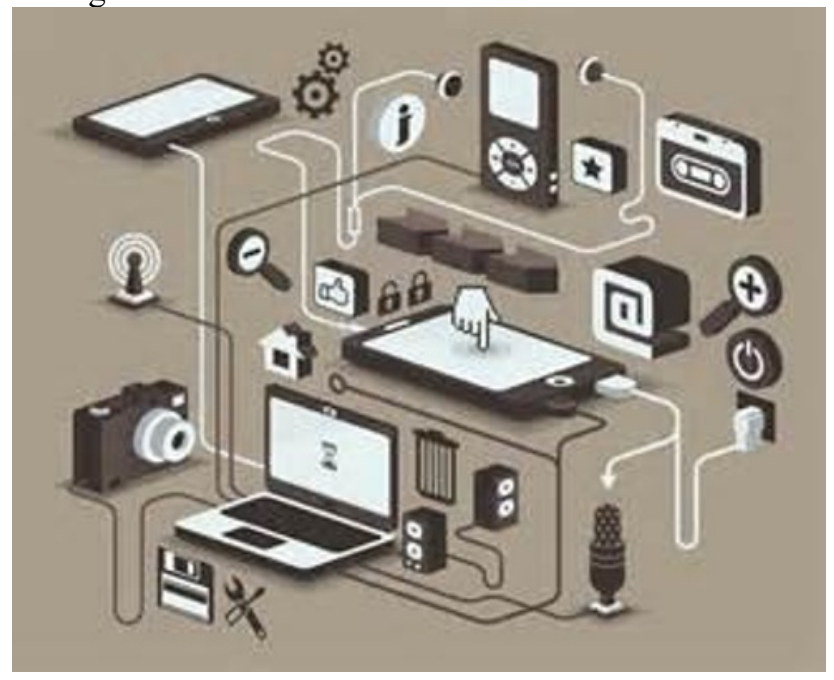

Fig. 3. Computer information Hardware topology system

\section{The trend of network development of distance learning platform}

Network teaching of college, graduate students and the community in terms of re-learning, more emphasis is self-learning mode. Thus, the status of teachers has undergone major changes, from the foreground to the background, the position has been a great impact on the teachers to make the teaching content and effect can continue to meet the needs of students, we need to continue to improve their knowledge of information. The network resources can be said to be vast, how to quickly and accurately find the resources they need in the wide ocean of information boom, how to quickly determine the value of the resource and its choices, how to properly recombining the resources for their own use, able to reach out to computer hardware and software knowledge, or even develop their own courseware (this is critical), which are on the teachers put forward higher requirements. Here, however, we are not asking teachers to develop towards the direction of the programmer, but requires that the network culture, network technology to quickly accept the teachers' understanding of cutting-edge technology can continue to reach out constantly to find a more suitable way of teaching. It is because of information technology update speed quickly, in terms of teachers, made after a great opportunity, with new technology, new updates online teaching environment, using a variety of resources to enrich closed, isolated classroom, greatly expanded the amount of knowledge of teaching, so that students are no longer just the content of textbooks on learning, broaden the idea. Therefore, improving the teaching team building information literacy is key to the success of online education points.

"People want not technology or interaction itself, but devotion truly fruitful, touching experience" '. For the future of online education, for teachers, students, educational resources or education service Provider Company, no matter which party? In the era of technological development and technological innovation, technical network distance learning platform and it determines the development of open information technology related information every major technological breakthrough will effectively promote distance education has leapt to a new level. Development of distance education and new requirements appear in turn, become the internal drive technology development. The main trend of distance education technology development is to lead the development of the technological development of teaching; teaching began to demand-driven technology development and even leads the way forward.

Intelligence is an important trend in the development of distance education technology, intelligent calling attention to knowledge of media research, development and application. Knowledge of media is including knowledge (knowledge modelling, knowledge management, knowledge discovery), spread (collaborative learning, Web CT, electronic publishing, artificial agents) and media (educational multimedia, software visualization, streaming media, virtual labs), and other areas of research and study direction. Pay attention to its purpose (knowledge), process (propagation), and the body of the (media) study, the theory of knowledge, communication theory, media theory and technology into distance learning and teaching resources construction 
applications, with particular emphasis on organizing and guiding students to learn application of intelligent knowledge media to promote their own learning.

\section{Conclusion}

This paper mainly from two aspects of theory and technology of WEB-based computer art distance learning platform to do a certain amount of discussion and study. Mainly from technical theory streaming media technology, WEB3D technology and virtual experiments, this paper proposes, developed and used in the development of the Internet environment for art and design disciplines demand of $\mathrm{B} / \mathrm{S}$ computer-aided distance learning platform, given the practice of courseware design and model of the system, and complete some of the features of the system model.

Firstly, the research background, research status, and the source of the problem are purposed and significance of the thesis. It discusses the concept of network multimedia courseware and features, and analyses the status quo of network teaching, which points out the shortcomings that exist in the current network courseware.

Secondly, the advantages and disadvantages of traditional teaching art design teaching and multimedia network teaching, analyses the situation of modern art and design education, describes the multimedia network technology in teaching in art and design benefits, disadvantages, pointed out network teaching and traditional teaching combined, is the future direction of the art design teaching. Combined with their understanding of network teaching and traditional teaching, it gives some information on how to teach in Multimedia Network Learning in Cultivation of Creative Ability.

Again, from instructional design and system design of network courseware start, in the "constructivist" theory instruction, combined with "Poster Design" Courseware instance, he studied art and design teaching network courseware design process. Especially in the courseware system design section, detailed courseware interface elements: a summary text, graphics, colour, etc., organize and planning.

Finally, the network courseware development process summarized the process of network courseware, courseware development network operating environment and the development environment, edit and test and evaluation of courseware.

\section{References}

1. Liu Shiyan .part2 advertising design of the poster. Shaanxi People's Publishing House.

2. It can resist. Thinking about online teaching and traditional teaching model $[\mathrm{J}]$. Educational technology communications, 2002, (1).

3. Li Yong, a new experience in art design teaching methods - Art and design disciplines online learning development and research.East China University 2005.
4. Yuan Xi intestine. China Development of Art Design Education Research [M] Beijing Institute of Technology Press, 2003.7.

5. Xu Jiang. Thinking. Chongqing Radio and Television University of Art and Design on teaching reform, 2005, 17 (2).

6. Zhao Jun, ZHAO Yanxia. University Art Department of Art Design Teaching ascertain "J] Higher Education Research, 2005, 28.

7. Pan Lusheng Design Art Education sketches and notes " Shandong Pictorial Publishing House 2005.7.

8. Rui network education courseware development and meteorological network technology . Nanjing Institute of Meteorology 2002.

9. Zhu Xi Shu Impact On Computer Network Technology on the development of art and design education . Nanjing Institute of the Arts 2005

10. Ma Xiaojun. Practice of Multimedia Teaching in Art Design Teaching [J] Education Research, 2005.8, 11 (gift issue).

11. Ma Huihui. Multimedia courseware database . Based on 2001 Shandong Normal University.

12. Xia Lisheng Comparison and thinking of digital multimedia art theory education and traditional art theory education. China Art Technology. 2002 (internet multimediainternet multimedia)

13. Sun silver of Computer Art theory Teaching System in College Art theory Teaching Grand Week, 20internet multimediainternet multimedia, 3 (internet multimedia8): internet multimedia2-internet multimedia3

14. Zhang Hong digitized art theory teaching resources used in elementary art theory teaching Chinese art theory education, 20internet multimedia0, 6 (5): 2-3

15. Zhou Ya dragonfly modern ear training teaching philosophy research . Liaoning Normal University, 20internet multimedia0.

16. . Frozen Cultural Revolution reflection on social art theory education and art theory education in the family sound the Yellow River, 20internet multimedia0, 6 (7): 78-79

17. Zhao Yi Shan ear training course Beijing: Central University for Nationalities Publishing House, 20internet multimedia2, internet multimedia2 (9): 45-46

18. Yang ceremony Friends network teaching management and its platform PLA military training. Information Network academic papers Wuhan: Department of the General Staff Military, 2001: 1620

19. Design and Application Peican Ming, Wang Wenhua a distributed multimedia information system. computer with an external device, 1999 (5): 6-10

20. And Implementation Liu Yizhou, seats Hui just design Web-based distance education system. army military training information network academic papers, 2001: 28-31 
21. Hung Yi Design and Implementation of Multimedia Information System. Jinzhong Teachers College, 1999 (1): 65-68

22. Study Liu Jie multimedia distance education technology development status and problems of
China Distance Education Supplement, 2000: 144145

23. Li Lu A, Zheng Yanlin, Yang Bindeng, English education in the field of higher education network comparison. China Distance Education Supplement, 2000 (6): 122-123 